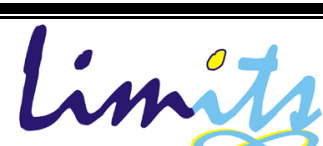

Limits: Journal of Mathematics and Its Applications

E-ISSN: 2579-8936

P-ISSN: 1829-605X

Vol. 18, No. 1, Mei 2021, 1-13

DOI: http://dx.doi.org/10.12962/limits.v18i1.6933

\title{
Prediksi Penyebaran Covid-19 di Indonesia dan Jawa Timur dengan Metode Extended Kalman Filter
}

\author{
Helisyah Nur Fadhilah ${ }^{1,2}$, Erna Apriliani ${ }^{1}$, Didik Khusnul Arif ${ }^{1}$ \\ ${ }^{1}$ Institut Teknologi Sepuluh Nopember, Surabaya \\ ${ }^{2}$ Institut Teknologi Telkom Surabaya, Surabaya \\ e-mail: helisyah07@gmail.com
}

Diajukan: 22 Mei 2020, Diperbaiki: 11 Februari 2021, Diterima: 22 Februari 2021

\begin{abstract}
Abstrak
Saat ini pandemi Covid-19 telah menyebar ke seluruh dunia, tidak terkecuali Indonesia. Dalam pemodelan matematika, penyebaran Covid-19 dapat digambarkan melalui model matematika epidemiologi SIRD (Susceptible, Infected, Recover, Death). Pertama model non-linier SIRD didiskritkan dan selanjutnya dilakukan prediksi puncak penyebaran Covid-19 dengan menggunakan metode Extended Kalman Filter (EKF). Dengan data aktual Infected, Recover, dan Death yang merupakan data harian, modifikasi EKF dapat memprediksi puncak infeksi Covid-19 untuk satu bulan kedepan. Simulasi dilakukan dengan 3 macam pembatasan pergerakkan pada masyarakat yaitu : tanpa adanya pembatasan (100\%), 75\%, dan 50\% pergerakkan. Hasil prediksi dengan modifikasi EKF menunjukkan dengan dilakukan pembatasan pergerakkan $50 \%$ pada masyarakat di Indonesia dan Jawa Timur dapat mempercepat terjadinya puncak infeksi dengan jumlah individu terinfeksi lebih sedikit.
\end{abstract}

Kata Kunci: Extended Kalman Filter, Prediksi EKF, Covid-19

\section{Abstract}

In recent years, the pandemic of Covid-19 has spread around the world, including Indonesia. In mathematical modeling, the spread of Covid-19 can be represented as the epidemiological mathematical model of SIRD (Susceptible, Infected, Recover, Death). First, we obtain the discrete SIRD nonlinear model, and then we predict the peak spread of Covid-19 by using the Extended Kalman Filter (EKF) method. With the daily data of Infected, Recover and Death, the modified EKF can predict the peak of Covid-19 infection for the next month. In the simulations, we use three types of restrictions of people mobility i.e., without restrictions (100\%), 75\%, and 50\% mobility. The prediction results with modified EKF show that restrictions on people's mobility in 50\% can accelerate the peak of infection with smaller infected individuals in Indonesia and East Java.

Keywords: Extended Kalman Filter, EKF prediction, Covid-19

\section{Pendahuluan}

Saat ini penyakit yang disebabkan oleh virus Corona atau sering disebut Corona Virus Disease 2019 (Covid-19) telah menjadi pandemi dan menyebabkan keprihatinan di seluruh dunia. Penyebaran Covid-19 merupakan ancaman serius bagi kesehatan global. Dikutip dari situs Organisasi Kesehatan Dunia (WHO) pada Rabu (13/5/2020) Tingkat kematian akibat Covid-19 
adalah 6,7\%. Perlu dicatat bahwa Covid-19 adalah penyakit yang sedang berlangsung sehingga tingkat kematiannya belum final dan kemungkinan besar akan meningkat.

Pandemi Covid-19 masih menghantui banyak negara, khususnya di Indonesia. Sejak kasus pertama diumumkan, lonjakan pasien positif terus terjadi dan kian meningkat. Update sebaran Covid-19 pada Jumat (10/4/2020) mengatakan bahwa wabah Covid-19 sudah menyebar di seluruh Indonesia. Dikutip dari laman resmi kemkes.go.id, hingga Rabu (13/5/2020), jumlah kasus positif Covid-19 mencapai 15438, diikuti jumlah pasien sembuh sebanyak 3287 dan 1028 pasien lainnya meninggal dunia. Hingga Rabu (13/5/2020) provinsi Jawa Timur menempati posisi kedua sebagai provinsi dengan kasus positif terbanyak yakni 1766 dengan 278 pasien sembuh dan 166 pasien meninggal. Berdasarkan data tersebut, dapat dihitung tingkat kematian akibat Covid-19 di Indonesia adalah 6,7\% artinya sama dengan tingkat kematian akibat Covid-19 di dunia sedangkan tingkat kematian di Jawa Timur adalah 9,4\%, artinya tingkat kematian akibat Covid-19 di Jawa Timur lebih tinggi dibandingkan tingkat kematian secara nasional dan dunia.

Penyebaran pandemi Covid-19 dapat digambarkan melalui model matematika epidemiologi. Model matematika SIRD (Susceptible, Infected, Recover, Death) digunakan oleh beberapa peneliti untuk menggambarkan pola penyebaran virus Covid-19 [1][2]. Model SIRD merupakan modifikasi dari model SIR dimana di dalamnya ditambah satu variabel baru yakni variabel jumlah kematian (Death). Studi penyebaran pandemi Covid-19 berdasarkan model SIRD juga dilakukan oleh beberapa peneliti. Fanelli dkk [3] menggunakan model SIRD untuk memprediksi penyebaran Covid-19 di China, Italia, dan Iran. Penentuan parameter model dilakukan dengan menggunakan stochastic differential evolution. Metode Kalman filter yang terintegrasi dengan model SIR telah dibahas oleh Qian dkk [4] dengan hasil yang cukup baik.

Pada makalah ini, akan dilakukan prediksi penyebaran Covid-19 di Indonesia dan Jawa Timur berdasarkan model SIRD dengan menggunakan metode Extended Kalman Filter (EKF) [5]. Modifikasi EKF dilakukan untuk mengasilkan prediksi beberapa bulan kedepan. Tujuan dari prediksi penyebaran Covid-19 dengan modifikasi EKF adalah memberikan gambaran pada masyarakat bagaimana dinamika penyebaran Covid-19 jika diberikan 3 macam pembatasan pergerakkan pada masyarakat, sehingga diharapkan dapat menjadi referensi bagi pemerintah pusat maupun daerah dalam mengambil kebijakan untuk menekan penyebaran Covid-19 di Indonesia dan Jawa Timur. 


\section{Model SIRD}

Dalam model kompartemen SIRD diasumsikan bahwa setiap individu dalam kompartemen yang sama memiliki karakteristik yang sama. Model SIRD dengan empat kompartemen diberikan seperti pada Gambar $1[1]$.

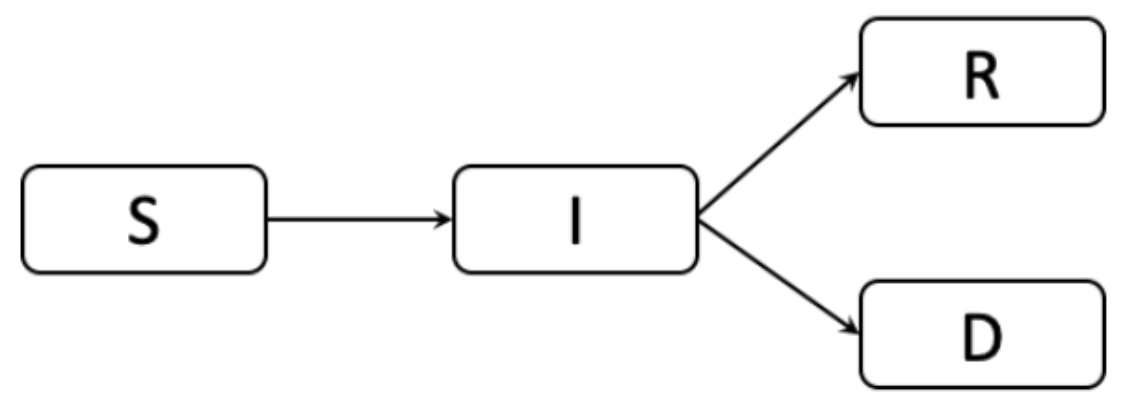

Gambar 1. Kompartemen model SIRD

dengan $S$ adalah kompartemen rentan, $I$ adalah kompartemen terinfeksi, $R$ adalah kompartemen sembuh, dan $D$ adalah kompartemen kematian.

Diasumsikan bahwa total populasi adalah konstan, yang berarti bahwa dalam periode waktu yang dipertimbangkan laju kelahiran dan kematian (termasuk yang terkait dengan Covid-19) adalah sama [6]. Hal ini terutama berlaku untuk penyakit mematikan yang rendah dengan wabah yang sangat besar. Selanjutnya diasumsikan bahwa orang yang pulih tidak dapat terinfeksi kembali [7]. Persamaan diferensial biasa, dengan masing-masing kondisi awal, yang menggambarkan pergerakan orang dari satu kompartemen ke yang lain dapat dituliskan dalam Persamaan (1)-(4) berikut.

$$
\begin{aligned}
& \dot{S}(t)=-r S(t) I(t) \\
& \dot{I}(t)=r S(t) I(t)-(a+d) I(t) \\
& \dot{R}(t)=a I(t) \\
& \dot{D}(t)=d I(t)
\end{aligned}
$$

dengan,

- $\quad r$ adalah parameter laju infeksi, yaitu probabilitas per satuan waktu yang menyatakan bahwa seseorang yang rentan $(S)$ penyakit ketika melakukan kontak dengan orang yang terinfeksi,

- $\quad a$ adalah parameter laju kesembuhan $(R)$ seseorang per satuan waktu setelah terinfeksi,

- $\quad d$ adalah parameter laju kematian $(D)$ seseorang per satuan waktu setelah terinfeksi. 


\section{Extended Kalman Filter}

Metode Extended Kalman Filter adalah modifikasi dari metode Kalman Filter yang digunakan untuk estimasi sistem dinamik stokastik non-linier [5]. Perbandingan antara algoritma Kalman Filter (KF) dan Extended Kalman Filter (EKF) dapat dilihat pada Tabel 1 berikut [8].

Tabel 1. Tabel perbandingan algoritma Kalman Filter dan Extended Kalman Filter

\begin{tabular}{cc}
\hline Kalman Filter (KF) & Extended Kalman Filter (EKF) \\
\hline Model Sistem dan Pengukuran & Model Sistem dan Pengukuran \\
\hline$x_{k+1}=A x_{k}+B u_{k}+G w_{k}$ & $x_{k+1}=f\left(x_{k}, u_{k}, w_{k}, k\right)$ \\
$z_{k+1}=H_{k+1} x_{k+1}+v_{k}$ & $z_{k}=h\left(x_{k}, v_{k}, k\right)$ \\
\hline Inisialisasi & Inisialisasi \\
\hline$x_{0} N\left(\bar{x}, P_{0}\right)$ & $x_{0} N\left(\bar{x}, P_{0}\right)$ \\
\hline Tahap Prediksi & Tahap Prediksi \\
\hline$x_{k+1}^{-}=A x_{k}+B u_{k}$ & $x_{k+1}^{-}=f\left(x_{k}, u_{k}\right)$ \\
$P_{k+1}^{-}=A P_{k} A^{T}+B u_{k}+G Q G^{T}$ & $A P_{k} A^{T}+B u_{k}+G Q G^{T}$ \\
& $A=\frac{\partial f}{\partial x} ; B=\frac{\partial f}{\partial u}$ \\
\hline Tahap Koreksi & Tahap Koreksi \\
\hline$K_{k+1}=(I-K H) P_{k+1}^{-}$ & $K_{k+1}=(I-K H) P_{k+1}^{-}$ \\
$P_{k+1}=P_{k+1}^{-} H^{T}\left(H P_{k+1}^{-} H^{T}+R\right)^{-1}$ & $P_{k+1}^{-} H^{T}\left(H P_{k+1}^{-} H^{T}+R\right)^{-1}$ \\
$x_{k+1}=x_{k+1}^{-}+K\left(z_{k+1}-H_{k} x_{k+1}^{-}\right)$ & $P_{k+1}^{-}+K\left(z_{k+1}-h\left(x_{k+1}^{-}\right)\right)$ \\
$x_{k+1}$ & $H=\frac{\partial h}{\partial x}$ \\
& $x_{k+1}$ \\
&
\end{tabular}

Dalam KF, model sistem yang digunakan adalah linier, sedangkan dalam EKF, pelinieran hanya dilakukan untuk memperoleh matriks $A$ dan $H$ yang digunakan dalam menghitung kovariansi pada tahap prediksi, tahap koreksi, dan untuk menghitung Kalman gain.

Tahap prediksi yaitu memprediksi variabel keadaan dan tingkat akurasinya dihitung menggunakan persamaan kovarian eror atau norm kovariansi eror. Pada tahap koreksi, hasil estimasi variabel keadaan dikoreksi menggunakan model pengukuran. Salah satu bagian dari tahap ini yaitu menentukan matriks Kalman Gain yang digunakan untuk meminimumkan kovariansi eror. Tahap prediksi dan tahap koreksi akan diulang terus menerus sampai waktu $k$ yang ditentukan. 
Pada KF dan EKF, keduanya dapat melakukan prediksi satu satuan waktu kedepan (one step ahead) berdasarkan model matematika, dalam hal ini SIRD. Model SIRD merupakan model sistem non-linier sehingga pada makalah ini digunakan metode EKF untuk prediksi. Pada hasil prediksi kemudian dilakukan koreksi berdasarkan data pengukuran. Sehingga perlu adanya modifikasi algoritma untuk dapat melakukan prediksi dengan keterbatasan data pengukuran/data aktual sehingga waktu prediksi yang didapatkan bisa lebih panjang.

Prediksi EKF adalah salah satu modifikasi EKF. Keterbatasan data aktual merupakan salah satu kendala dalam melakukan prediksi jauh kedepan, maka dalam prediksi EKF dilakukan modifikasi algoritma pada tahap prediksi. Tahap prediksi EKF pada Tabel 1 tidak terdapat noise model, noise digunakan pada kovarian tahap prediksi dan diperbaiki pada tahap koreksi.

Ketika data prediksi pengukuran telah habis (tidak ada), maka dapat dibangkitkan sebuah data pengukuran dari hasil estimasi waktu satuan sebelumnya $x_{k-1}$, sehingg data bangkitan tersebut dapat digunakan pada tahap koreksi. Dapat dikatakan, selama data pengukuran masih ada, maka proses estimasi berjalan sesuai dengan algoritma EKF pada Tabel 1, setelah data habis maka prediksi EKF yang digunakan sampai waktu yang ditentukan.

Misalkan diberikan persamaan model sistem non-linier dan pengukuran sebagai berikut.

$$
\begin{aligned}
x_{k+1} & =f\left(x_{k}, w_{k}, k\right) \\
z_{k} & =h\left(x_{k}, v_{k}, k\right)
\end{aligned}
$$

dengan $f$ adalah fungsi non-linier yang bergantung pada variabel keadaan $x_{k}, h$ adalah matriks pengamatan, $w_{k}$ adalah noise model dengan $w_{k} \sim(0, Q)$, dan $v_{k}$ noise pengukuran dengan $v_{k} \sim(0, R)$. Persamaan (6) diasumsikan tidak memiliki input sistem.

Misalkan terdapat data pengukuran sebanyak $x_{k}$ data, maka dapat dicari estimasi data ke $x_{k+1}$ dengan menggunakan algoritma EKF pada Tabel 1.

Selanjutnya untuk prediksi $x_{n+1}$ dengan $n>k$ bilangan bulat dan selisih $n-k=1$ atau $n=k+1$. Dilakukan inisialisasi model dan pengukuran yaitu

$$
\begin{gathered}
x_{n+1}=f\left(x_{n}, j_{n}, n\right) \\
z_{n+1}=h\left(x_{n}, q_{n}, n\right)
\end{gathered}
$$

dengan $j_{n}$ dan $q_{n}$ masing-masing noise sistem dan noise pengukuran dengan $j_{n} \sim(0, B)$ dan $q_{n} \sim(0, L)$. Pada Persamaan (8), data pengukuran dibangkitkan dengan deta hasil estimasi ditambah noise.

Proses prediksi EKF pada makalah ini dapat digambarkan pada Gambar 2 berikut. 


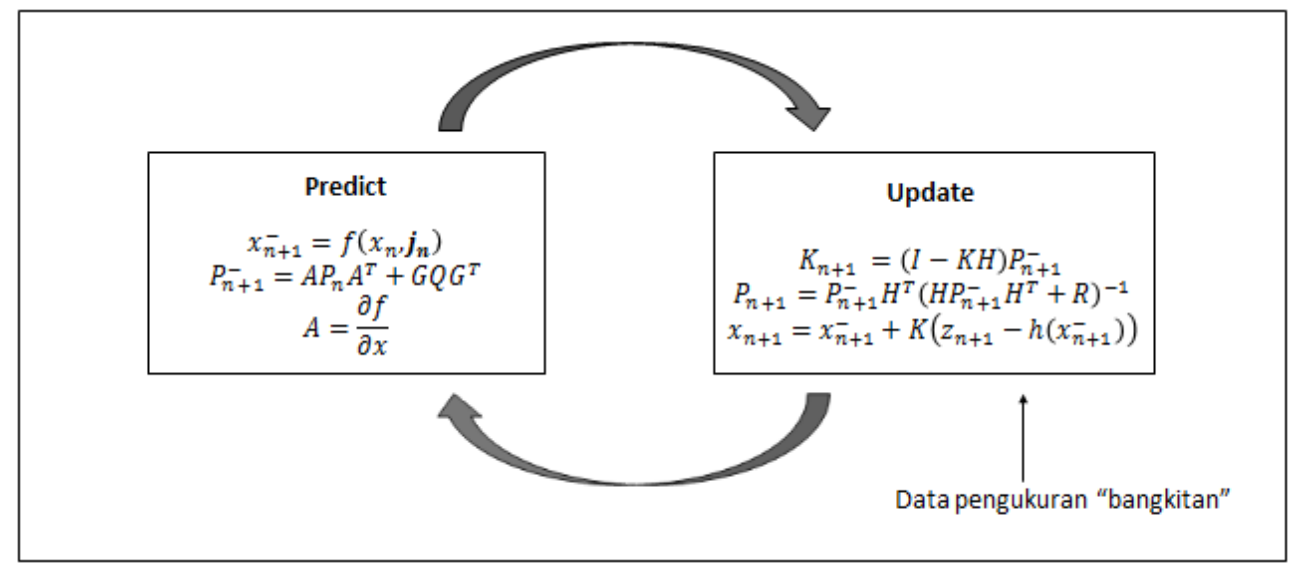

Gambar 2. Algoritma prediksi EKF pada model SIRD

Selanjutnya, akan dilakukan simulasi prediksi EKF pada model SIRD (1)-(4) untuk mengetahui prediksi penyebaran Covid-19 di Indonesia dan di Jawa Timur.

\section{Simulasi}

Pada bagian ini akan diterapkan metode prediksi Extended Kalman Filter (EKF) untuk memprediksi penyebaran Covid-19 dengan model SIRD dan mengetahui puncak Infeksi (I). Untuk mengaplikasikan metode prediksi EKF diperlukan model linier untuk matriks $\boldsymbol{A}$. Dari sini terlebih dahulu dilakukan pelinieran dengan membentuk matriks Jacobian dari Persamaan (1)-(4). Titik setimbang diperoleh $(\boldsymbol{S}, \boldsymbol{I}, \boldsymbol{R}, \boldsymbol{D})=\left(\frac{\boldsymbol{a}+\boldsymbol{d}}{\boldsymbol{r}}, \mathbf{0}, \mathbf{0}, \mathbf{0}\right)$. Hasil linierisasi pada titik setimbang adalah sebagai berikut.

$$
A=\left[\begin{array}{ccccccc}
1 & 0 & 0 & 0 & 0 & 0 & 0 \\
0 & 1 & 0 & 0 & 0 & 0 & 0 \\
0 & 0 & 1 & 0 & 0 & 0 & 0 \\
0 & 0 & 0 & 0 & -(a+d) & 0 & 0 \\
0 & 0 & 0 & 0 & 1 & 0 & 0 \\
0 & 0 & 0 & 0 & a & 0 & 0 \\
0 & 0 & 0 & 0 & d & 0 & 0
\end{array}\right]
$$

Selanjutnya di cari pendiskritan dari model non-linier (1)-(4) sebagai berikut:

$$
\begin{gathered}
S_{k}=-r S_{k}^{-} I_{k}^{-} d t+S_{k}^{-}, \\
I_{k}=\left[r S_{k}^{-} I_{k}^{-}-(a+d) I_{k}^{-}\right] d t+I_{k}^{-}, \\
R_{k}=a I_{k}^{-} d t+R_{k}^{-}, \\
D_{k}=d I_{k}^{-} d t+D_{k}^{-} .
\end{gathered}
$$

Selanjutnya digunakan algoritma genetika [9] untuk mendefinisikan nilai awal parameter $\boldsymbol{r}, \boldsymbol{a}, \boldsymbol{d}$, dan nilai awal state $\boldsymbol{S}_{\mathbf{0}}$. Dalam simulasi masing-masing akan diprediksi berdasarkan kebijakan pembatasan pergerakan yang telah dikeluarkan pemerintah baik pusat dan daerah Jawa Timur. Faktor pergerakan dilakukan dengan cara mengalikan parameter $\boldsymbol{r}$ dengan faktor pengali 100\%, $75 \%$, dan $50 \%$. 


\section{Kasus Indonesia}

Pada bagian ini akan disimulasikan prediksi penyebaran Covid-19 di Indonesia dengan metode prediksi EKF. Data aktual I, R, dan D diambil dari kawalcovid19.id yang dimulai tanggal 2/3/2020 sampai 13/5/2020. Diasumsikan bahwa tidak semua penduduk Indonesia yang tidak terpapar Covid-19 merupakan individu yang rentan. Hal tersebut cukup beralasan karena paparan Covid-19 selama ini lebih banyak mengenai penduduk di pulau Jawa, Bali, dan Sumatera yang merupakan pulau dengan penduduk terbanyak di Indonesia. Sedangkan beberapa pulau yang bukan padat penduduk, kasus Covid-19 masih tergolong kecil.

Oleh karena itu, nilai awal $\boldsymbol{S}_{\mathbf{0}}$ dihitung dengan menggunakan algoritma genetika untuk mendapatkan jumlah individu yang rentan pada simulasi ini. Didapatkan nilai awal dengan algoritma genetika seperti pada Tabel 2 berikut:

Tabel 2. Nilai awal parameter kasus Indonesia

\begin{tabular}{cc}
\hline Parameter & Nilai \\
\hline$S_{0}$ & 24000 \\
\hline$r$ & $2.95095 \times 10^{-6}$ \\
\hline$a$ & 0.011731133 \\
\hline$d$ & 0.005463589 \\
\hline
\end{tabular}

Pada simulasi ini, nilai awal $\boldsymbol{S}_{\mathbf{0}}$ tidak diambil dari data real penduduk Indonesia yang tidak terpapar Covid-19, melainkan dihitung dengan menggunakan algoritma genetika. Hal tersebut dilakukan Hasil simulasi penyebaran Covid-19 di Indonesia dengan metode prediksi EKF ditunjukkan pada Gambar 3-5.

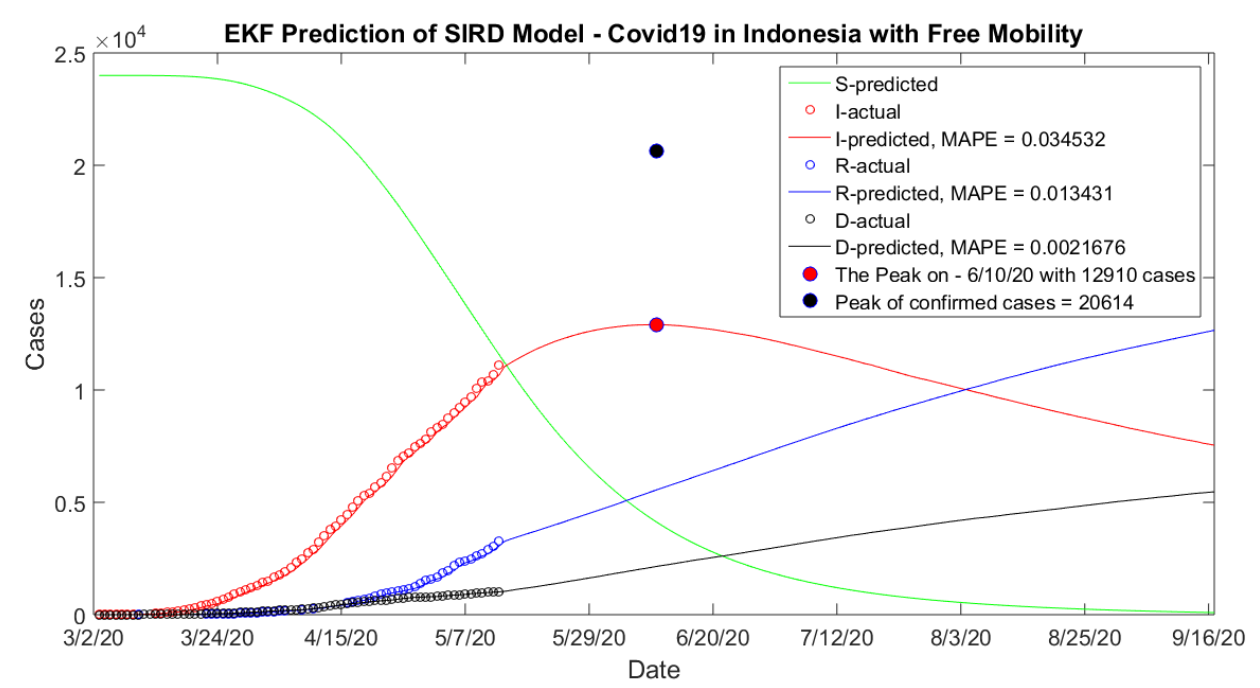

Gambar 3. Penyebaran Covid-19 di Indonesia tanpa pembatasan pergerakan dengan EKF 


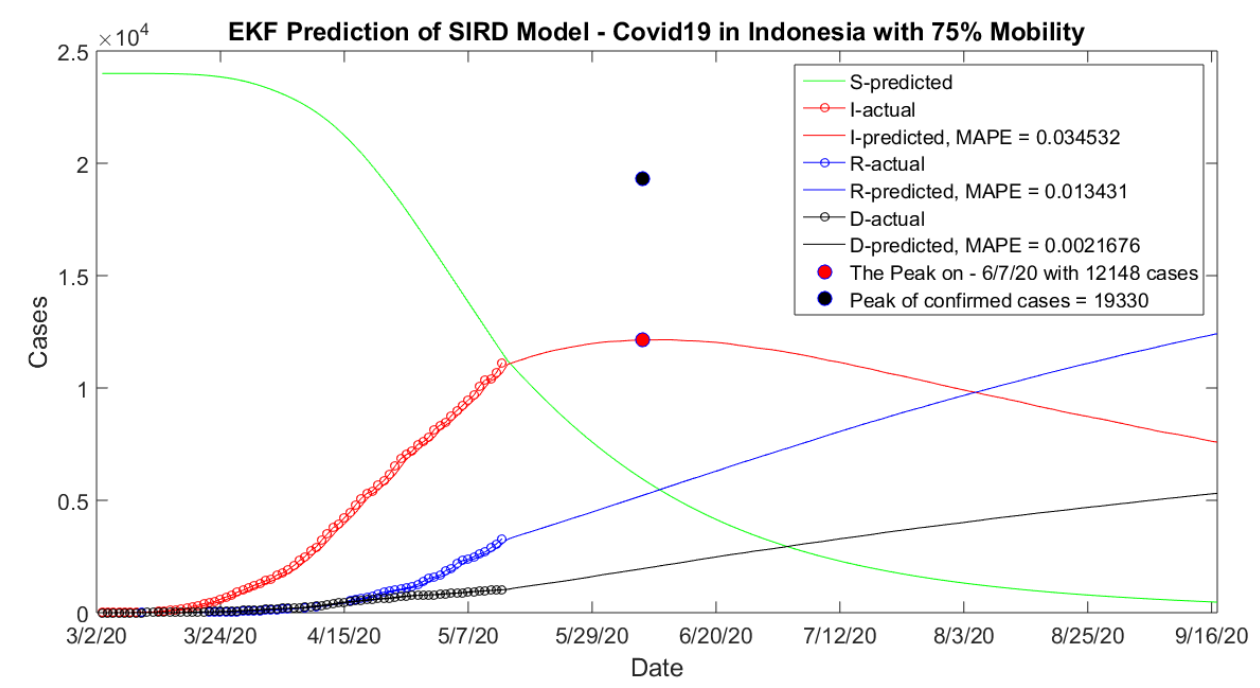

Gambar 4. Penyebaran Covid-19 di Indonesia dengan pergerakan 75\% dengan metode prediksi EKF

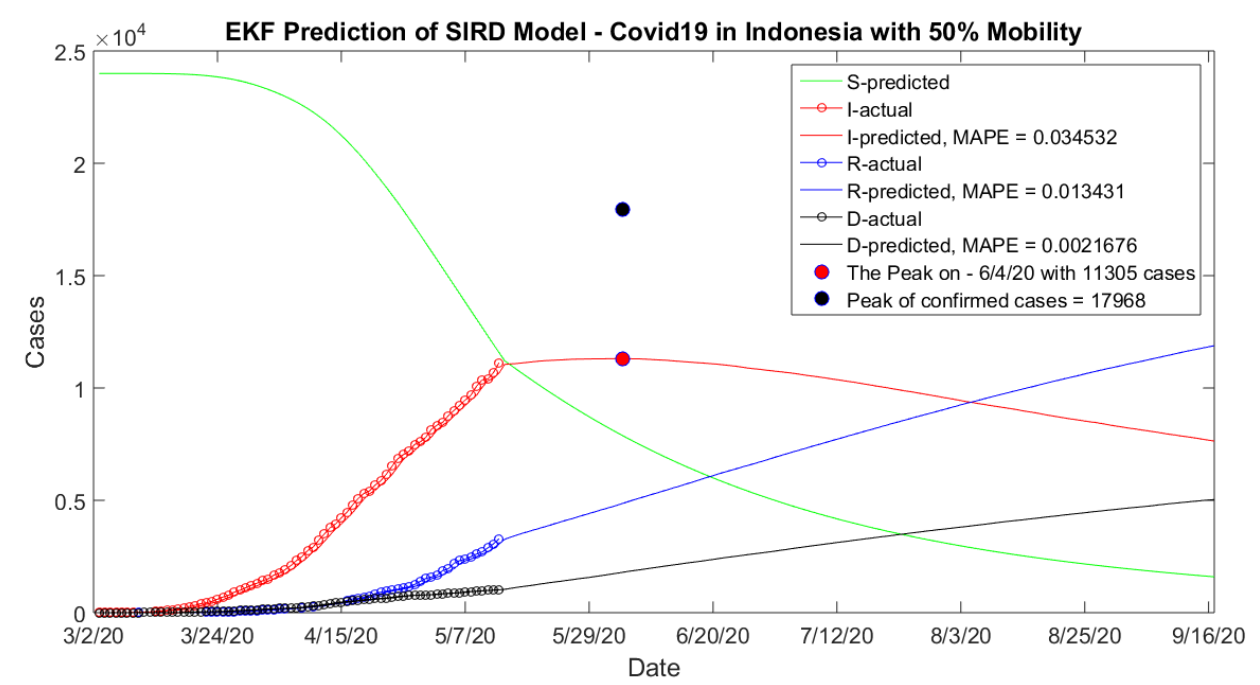

Gambar 5. Penyebaran Covid-19 di Indonesia dengan pergerakan 50\% dengan metode prediksi EKF

Dapat dilihat pada Gambar 3-5 grafik I memiliki puncak pada waktu yang berbeda-beda dan total infeksi yang berbeda pula pada masing-masing kasus. Untuk grafik R dan D pada masingmasing kasus cenderung naik konstan. Hal tersebut dapat terjadi dikarenakan penambahan kasus sembuh dan meninggal setiap harinya cendurung sedikit dan konstan, hal sebaliknya terjadi pada kasus infeksi dimana penambahan kasus infeksi di Indonesia cenderung naik dengan penambahan yang besar pada setiap harinya.

Grafik infeksi Covid-19 di Indonesia dengan tiga macam pembatasan pergerakkan pada Gambar 3-5 dapat dirangkum pada pada Gambar 6 berikut. 


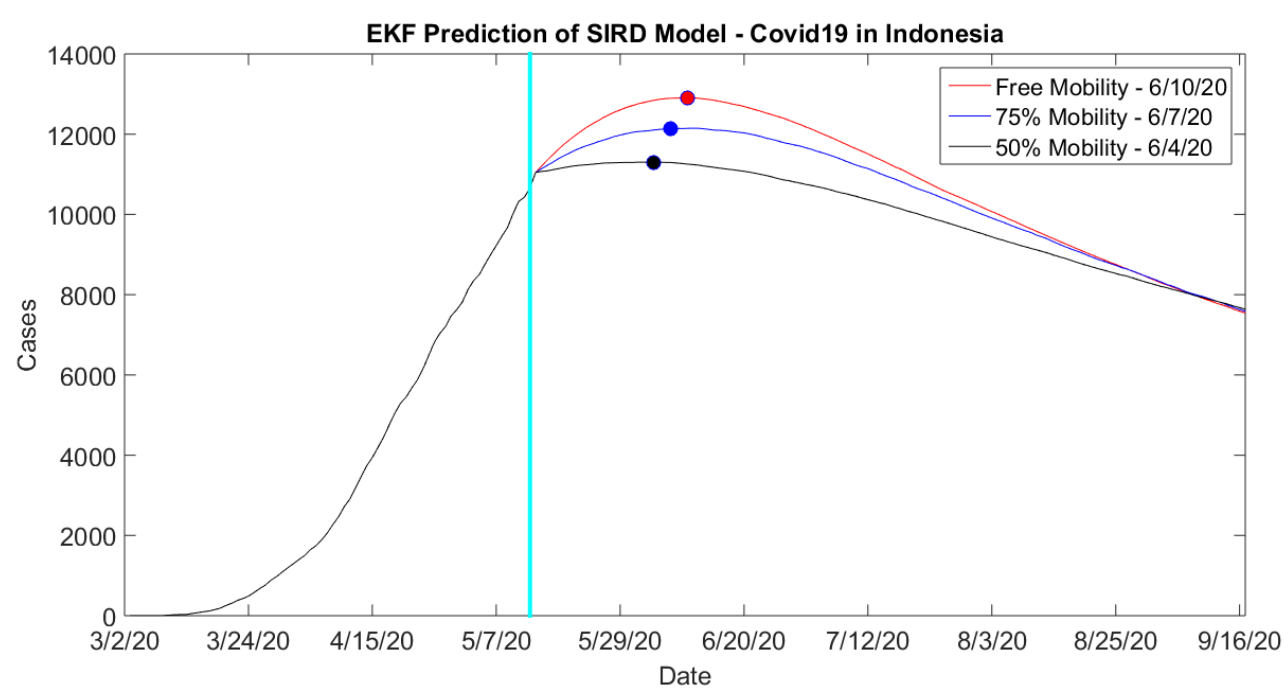

Gambar 6. Grafik individu terinfeksi Covid-19 di Indonesia dengan 3 macam faktor pergerakan dengan metode prediksi EKF

Berdasarkan Gambar 6, puncak infeksi Covid-19 di Indonesia dengan pembatasan pergerakkan $75 \%$ dan $50 \%$ memiliki puncak yang lebih landai dibandingkan tanpa adanya pembatasan pergerakkan. Dengan pelambatan puncak infeksi pada pembatasan pergerakkan, diharapkan tenaga medis dapat lebih maksimal dalam menangani pasien Covid-19 dan collapse rumah sakit rujukan Covid-19 di Indonesia dapat dihindari.

Tabel 3. Hasil prediksi puncak infeksi dan total individu terinfeksi Covid-19 di Indonesia

\begin{tabular}{cccc}
\hline No & Pergerakan & Puncak infeksi & Total individu terinfeksi pada puncak infeksi \\
\hline 1 & $100 \%$ & $10 / 6 / 2020$ & 12910 \\
\hline 2 & $75 \%$ & $7 / 6 / 2020$ & 12148 \\
\hline 3 & $50 \%$ & $4 / 6 / 2020$ & 11035 \\
\hline
\end{tabular}

Pada simulasi, pembatasan pergerakan (mobility) dimulai tanggal 14/5/2020. Berdasarkan Tabel 3, pembatasan pergerakan dapat mempengaruhi kecepatan puncak infeksi dan jumlah individu terinfeksi. Khusus kasus penyebaran Covid-19 di Indonesia, pembatasan pergerakan dapat mempercepat terjadinya puncak infeksi dengan total individu yang terinfeksi pada puncak infeksi lebih sedikit.

\section{Kasus Jawa Timur}

Pada bagian ini akan dilakukan simulasi kedua yaitu prediksi penyebaran Covid-19 di Jawa Timur dengan metode prediksi EKF. Data aktual I, R, dan D diambil dari detik.com yang dimulai 
tanggal 18/3/2020 sampai 13/5/2020. Didapatkan nilai awal dengan algoritma genetika seperti pada Tabel 4 berikut:

Tabel 4. Nilai awal parameter kasus Jawa Timur

\begin{tabular}{cc}
\hline Parameter & Nilai \\
\hline$S_{0}$ & 4300 \\
\hline$r$ & $2.18505 \times 10^{-5}$ \\
\hline$a$ & 0.01407089 \\
\hline$d$ & 0.008476428 \\
\hline
\end{tabular}

Hasil simulasi penyebaran Covid-19 di Jawa Timur dengan metode prediksi EKF ditunjukkan pada Gambar 7-9.

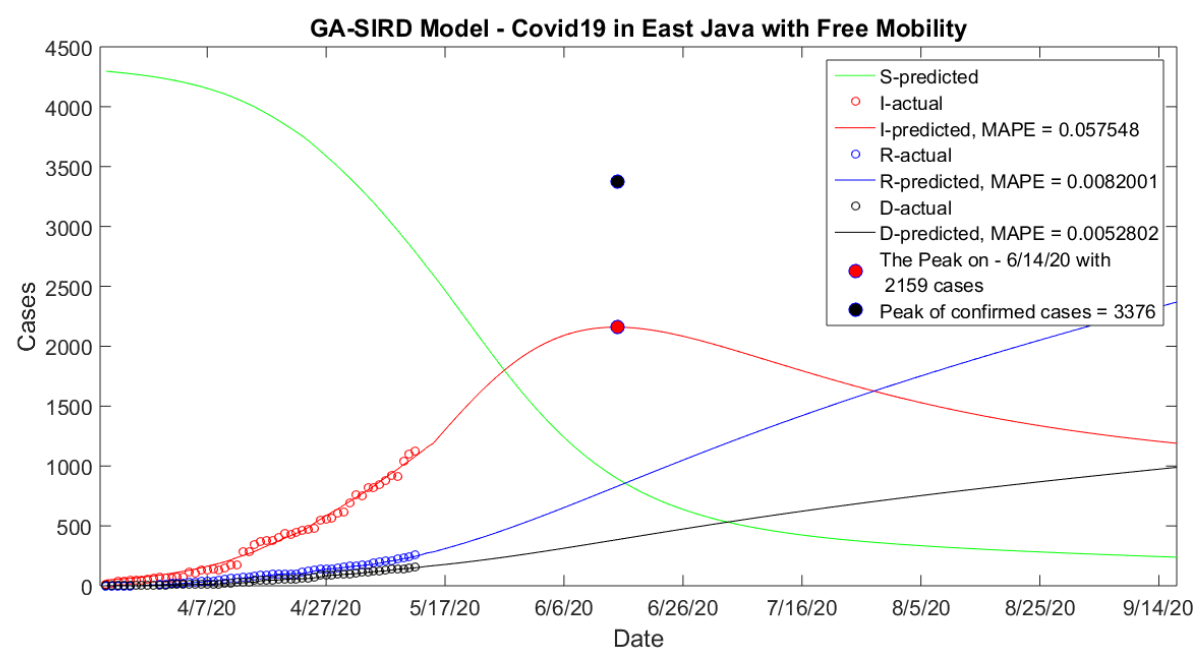

Gambar 7. Penyebaran Covid-19 di Jawa Timur tanpa pembatasan pergerakan dengan metode prediksi EKF

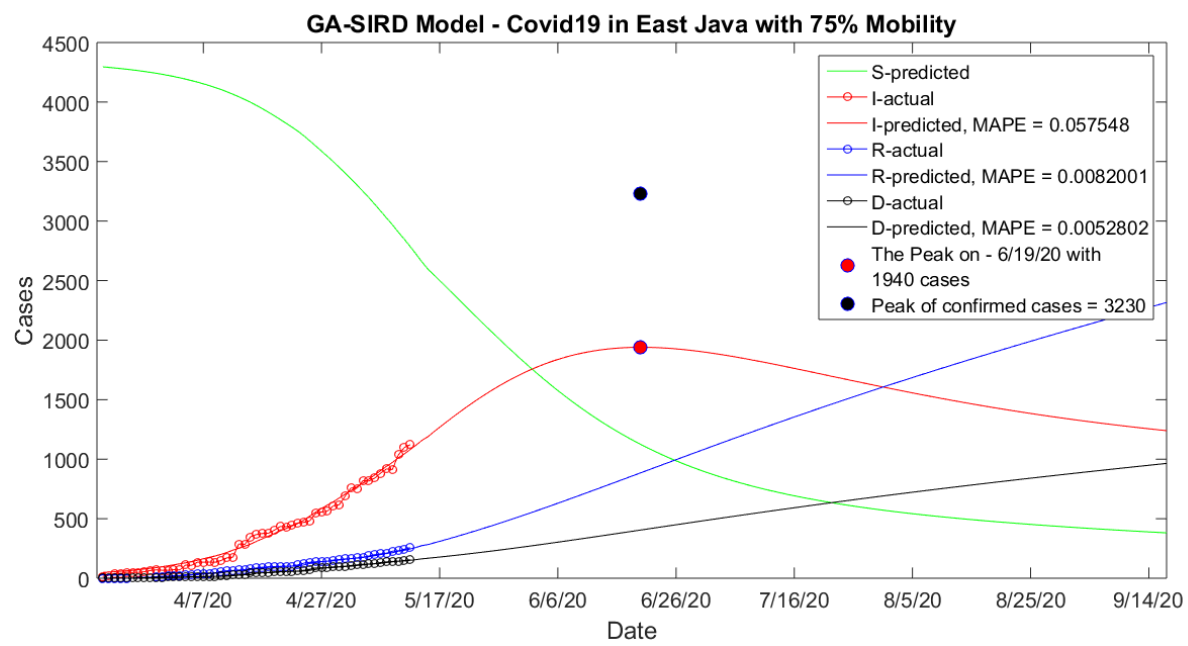

Gambar 8. Penyebaran Covid-19 di Jawa Timur dengan pergerakan 75\% dengan metode prediksi EKF 


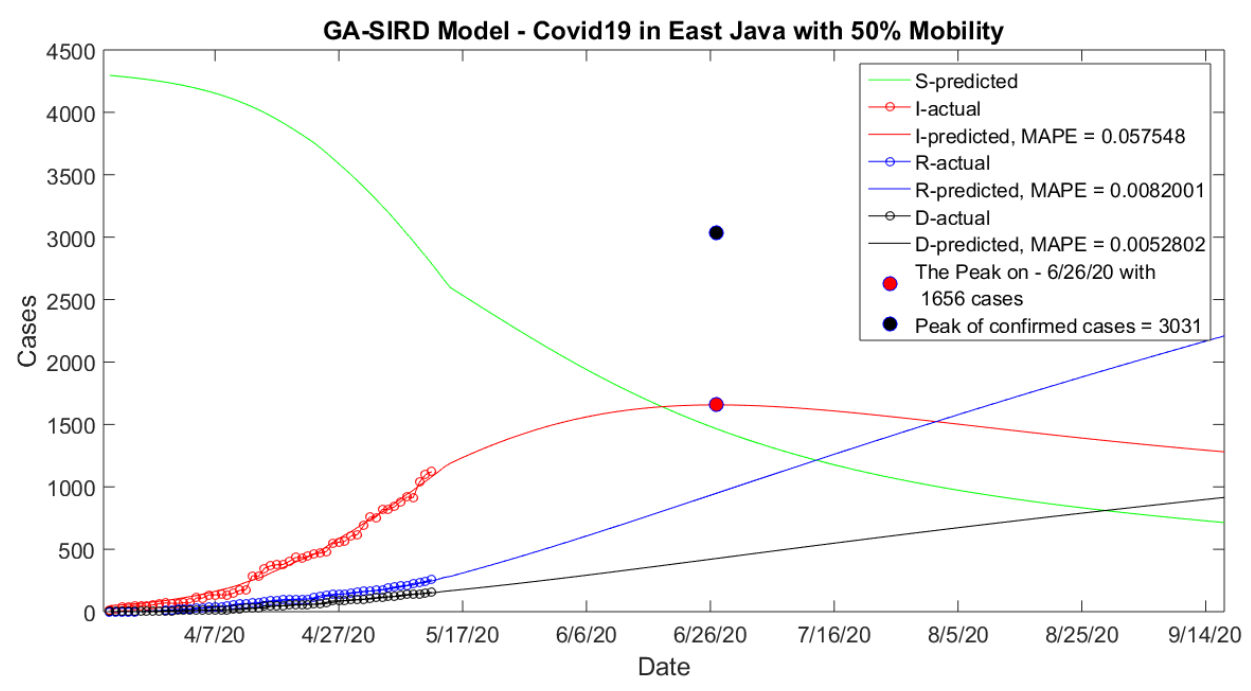

Gambar 9. Penyebaran Covid-19 di Jawa Timur dengan pergerakan 50\% dengan metode prediksi EKF

Dapat dilihat pada Gambar 7-9 grafik I memiliki puncak pada waktu yang berbeda-beda dan total infeksi yang berbeda pula pada masing-masing kasus. Untuk grafik R dan D pada masingmasing kasus cenderung naik konstan

Dapat dibandingkan grafik infeksi berdasarakan Gambar 7-9 pada Gambar 10 berikut.

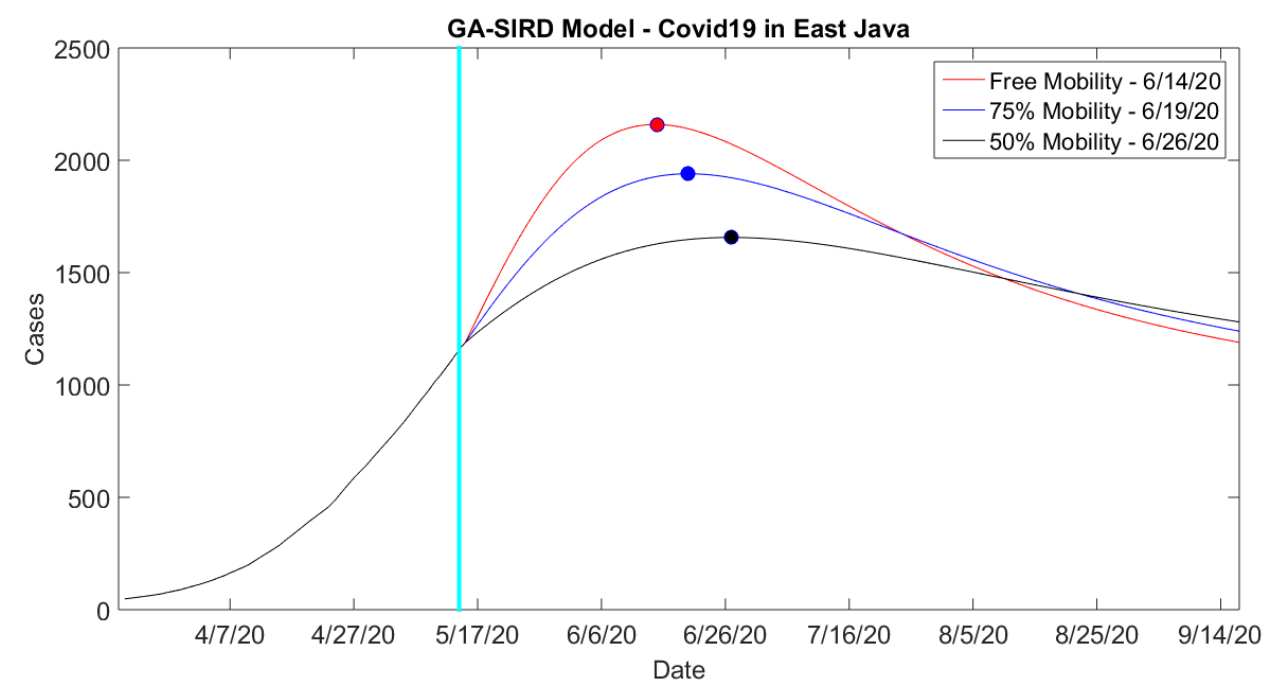

Gambar 10. Grafik individu terinfeksi Covid-19 di Jawa Timur dengan 3 macam faktor pergerakan dengan metode prediksi EKF

Berdasarkan Gambar 10, puncak infeksi dengan pembatasan pergerakkan memiliki puncak yang lebih landai dibandingkan tanpa adanya pembatasan pergerakkan. Dengan pelambatan puncak infeksi pada pembatasan pergerakkan 75\% dan 50\%, diharapkan tenaga medis dapat lebih maksimal dalam menangani pasien Covid-19 dan collapse rumah sakit di Jawa Timur akibat membeludaknya pasien Covid-19 dapat dihindari. 
Tabel 4. Hasil prediksi puncak infeksi dan total individu terinfeksi Covid-19 di Jawa Timur dengan metode prediksi EKF

\begin{tabular}{cccc}
\hline No & Pergerakan & Puncak infeksi & Total individu terinfeksi pada puncak infeksi \\
\hline 1 & $100 \%$ & $14 / 6 / 2020$ & 2159 \\
\hline 2 & $75 \%$ & $19 / 6 / 2020$ & 1940 \\
\hline 3 & $50 \%$ & $26 / 6 / 2020$ & 1656 \\
\hline
\end{tabular}

Pada simulasi, pembatasan pergerakan (mobility) dimulai tanggal 14/5/2020. Berdasarkan Tabel 4, pembatasan pergerakan dapat mempengaruhi kecepatan puncak infeksi dan jumlah individu terinfeksi. Berbeda dengan kasus di Indonesia secara umum, khusus kasus penyebaran Covid-19 di Jawa Timur pembatasan pergerakan dapat mempercepat terjadinya puncak infeksi dengan total individu yang terinfeksi pada puncak infeksi lebih sedikit.

\section{Simpulan}

Berdasarkan hasil simulasi prediksi penyebaran Covid-19 baik di Indonesia dan di Jawa Timur dapat dilakukan dengan metode prediksi EKF pada model SIRD. Pembatasan pergerakan dilakukan dalam simulasi yaitu faktor pergerakkan $100 \%, 75 \%$, dan $50 \%$, dapat disimpulkan bahwa kebijakan pembatasan pergerakan yang dikeluarkan pemerintah cukup efektif dan dapat menekan jumlah individu terinfeksi pada puncak infeksi berlangsung.

\section{Daftar Pustaka}

[1] D. Caccavo, "Chinese and Italian COVID-19 outbreaks can be correctly described by a modified SIRD model," medRxiv Prepr. doi https//doi.org/10.1101/2020.03.19.20039388, pp. 1-12, 2020.

[2] C. I. Jones and S. Gsb, "Estimating and Simulating a SIRD Model of COVID-19 for Many Countries, States, and Cities," 2020.

[3] N. Science, C. Phenomena, D. Fanelli, and F. Piazza, "Analysis and forecast of COVID-19 spreading in China, Italy and France," Chaos, Solitons Fractals Interdiscip. J. Nonlinear Sci. Nonequilibrium Complex Phenom., vol. 134, p. 109761, 2020.

[4] W. G. Kennedy and D. Hutchison, Social Computing, Behavioral-Cultural Modeling, and Prediction. Washington, DC: Springer Cham Heidelberg, 2014.

[5] A. N. A. Syarifudin, D. A. Merdekawati, and E. Apriliani, "Perbandingan Metode Kalman Filter, Extended Kalman Filter, dan Ensemble Kalman Filter pada Model Penyebaran Virus HIV / AIDS,” LIMITS, vol. 15, no. 1, pp. 17-29, 2018. 
[6] A. B. Gumel et al., "Modelling strategies for controlling SARS outbreaks," Proc. R. Soc. B Biol. Sci., vol. 271, no. 1554, pp. 2223-2232, 2004.

[7] L. Bao et al., "Reinfection could not occur in SARS-CoV-2 infected rhesus macaques," bioRxiv Prepr. doi https//doi.org/10.1101/2020.03.13.990226 ; pp. 1-17, 2020.

[8] L. Frank, L. Xie, and D. Popa, Optimal and Robust Estimation With an Introduction to Stochastic Control Theory, Second Edi. Boca Raton, FL: CRC Press, 2008.

[9] J. Mccall, "Genetic algorithms for modelling and optimisation," J. Comput. Appl. Math., vol. 184, pp. 205-222, 2005. 